\title{
PREVALENCE OF INTESTINAL PARASITES IN A POPULATION IN SOUTH OF TEHRAN, IRAN
}

\author{
Abolfath Shojaei ARANI(1), Reza AlAGHEHBANDAN(2), Lame AKHLAGHI(3), Maryam SHAHI(4) \& Abdolaziz Rastegar LARI(4)
}

\begin{abstract}
SUMMARY
The aim of this study was to describe epidemiologic characteristics of intestinal parasites in a population in south of Tehran, Iran. A retrospective cross-sectional study of patients with suspicious intestinal parasitic infections referred to the Zakaria Razi Laboratory in Shahre-Ray, southern Tehran, Iran, was conducted from April 21, 2004 to October 20, 2005. All stool samples were examined and socio-demographic informations were retrieved. Of 4,371 referred patients, 466 (239 males and 227 females) were laboratory diagnosed with intestinal parasites, with a period prevalence of 10.7\%. Blastocystis hominis (B. hominis) and Giardia lamblia (G. lamblia) were the most frequent intestinal parasites. More than half of patients aged $\geq 18$ years had a low level of educational attainment (e.g. illiterate, primary school, high school) (170/331, 54.1\%). Further, majority of patients were homemakers $(42.3 \%, 140 / 331)$ or workers $(28.1 \%, 93 / 331)$ employed in various business settings such as food industry and construction. Findings of this study showed that intestinal parasitic infections are still a major public health challenge in Iran that needs to be addressed. We believe that public education, improving sanitation conditions of underdeveloped areas/communities, community involvement, and supporting evidence-based practice/programs are the major keys to success in preventing the spread of intestinal parasitic infections in Iran.
\end{abstract}

KEYWORDS: Intestinal parasites; Epidemiology; Tehran, Iran.

\section{INTRODUCTION}

Intestinal parasitic infections are among the most common infections worldwide. It is estimated that approximately 3.5 billion people are affected and that 450 million are ill as a result of these infections, the majority being children ${ }^{15}$. Common intestinal parasites such as Blastocystis hominis (B. hominis) and Giardia lamblia ( $G$. lamblia) are still health challenges of economically developed and developing countries ${ }^{7}$. The prevalence of Blastocystosis in humans has been reported to be higher in developing countries (30-50\%) than in developed countries (1.5-10\%) and that B. hominis is the most common parasite in stool specimens in symptomatic and asymptomatic persons in a variety of settings ${ }^{7}$. Enterobius vermicularis (47.0\%), Trichuris trichiura (18.8\%) and Taenia saginata (17.2\%) were the most frequent intestinal parasites found in China ${ }^{29}$. In resource-poor countries of the world, G. lamblia is one of the first enteric pathogens to infect infants with peak prevalence of $15-30 \%$ occurring in children younger than 10 years $^{7}$.

Intestinal parasitic infections are historically common in $\operatorname{Iran}^{13,21,23}$. Although epidemiologic characteristics of these infections have been studied in some populations (mostly children) in Iran, a true and accurate picture of the magnitude of the problem is still unclear and

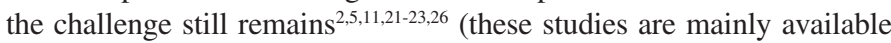

in the Persian literature). Further, interrelation between prevalence of intestinal parasites and socio-economic factors in Iran has not well been studied, given most of these studies are cross-sectional and/or descriptive $e^{2,5,11,13,21-23,26}$.

This study was designed to investigate epidemiologic features of intestinal parasites in an area with relatively high underprivileged population compared with the rest of the nation's capital (Tehran $)^{24}$. The authors intend to use the findings of this study as a foundation to support public health decision-making in the area of prevention and control strategies for intestinal parasitic infections.

\section{METHODS}

In 2005, Tehran had a population of 7,314,000 (metropolitan: $12,151,000)$ in a land area $^{24}$ of $658 \mathrm{~km}^{2}$. In the last two decades, Tehran faced a large migration of people from all around the country particularly from rural areas where they settled mostly in suburbs of southern part of the capital. This study took place in Shahre-Ray, a southern district (suburb) in Tehran with a population of $213,161^{24}$. According to the Statistical Center of Iran, the illiteracy rate in ShareRay was $21 \%$ compared to $9.4 \%$ in Tehran (for population aged $\geq 6$ years) $\left(\mathrm{P}_{(2)}<0.05\right)^{24}$. Further, the unemployment rate was reported to be higher in Share-Ray than in Tehran $(24.1 \%$ vs. $11.1 \%$ for population

(1) Faculty of Public Health, Iran University of Medical Sciences, Tehran, Iran.

(2) Research and Evaluation Department, Centre for Health Information, St. John's, NL, Canada.

(3) Department of Parasitology, Iran University of Medical Sciences, Tehran, Iran.

(4) Department of Microbiology, Iran University of Medical Sciences, Tehran, Iran.

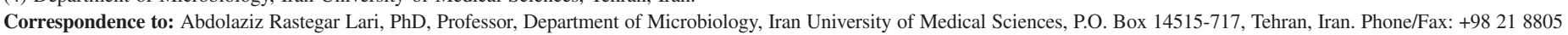
8649. Email: lari@iums.ac.ir 
aged $\geq 10$ years $)\left(\mathrm{P}_{(2)}<0.05\right)^{24}$. Available water supply is pipeline water system, although some may use welling water as their water supply. Garbage disposal is carried out by the municipal collection system.

This study was carried out at the Zakaria Razi Laboratory, a referral laboratory center in Shahre-Ray. Between April 21, 2004 and October 20, 2005, 4,371 patients with suspected intestinal infections were referred to the Zakaria Razi Laboratory from various health care facilities, out-patient clinics and private offices in the study area. All stool samples were processed within two hours of collection. Different stool examinations were used for efficacy in detecting parasites. These were direct wet-mount, formaldehyde-ether sedimentation method and modified acid-fast staining techniques ${ }^{3,18}$. Guide for Diagnosis of Intestinal Parasitosis was used as an identification reference ${ }^{27}$. All sociodemographic data (e.g., age, sex, level of education, occupation) were obtained from the main registry at the Zakaria Razi Laboratory and entered into a database. Data were analyzed using Statistical Program for Social Sciences (SPSS) for Windows 11.025 and differences were evaluated using the chi-squared test. All tests were two-sided with differences considered significant at $p<0.05$.

\section{RESULTS}

A total of 4,371 patients with suspected intestinal parasites were referred to the Zakaria Razi Laboratory including 2,288 females $(52.3 \%)$ and majority aged between $21-30$ years $(26.6 \%, 1163 /$ $4,371)$. Of 4,371 referred patients, 466 (10.7\%) (239 males and 227 females) were laboratory diagnosed with one or more intestinal parasites over the study period. Median age of the patients was 24 years with a range of $<2$ to 83 years. Table 1 presents distribution of intestinal parasites among the study population with $B$. hominis and $G$. lamblia being the most frequent intestinal parasites. No statistically significant difference was found between intestinal parasites and $\operatorname{sex}\left(\mathrm{P}_{(2)}>0.05\right)$.

Mean ( \pm SD) age of patients with B. hominis and G. lamblia were $27.9( \pm 16.3)$ and $24.8( \pm 17.7)$, respectively $\left(\mathrm{P}_{(2)}>0.05\right)$. Distribution of intestinal parasites according to age groups is shown in Table 2. Prevalence of $B$. hominis peaked at age 21-30 years, while prevalence of $G$. lamblia was higher in the younger than the older population. The prevalence of other parasites was relatively equal across all age groups.

Table 1

Distribution of intestinal parasites in a population in Shahre-Ray, Tehran, Iran

\begin{tabular}{|c|c|c|c|c|c|c|}
\hline \multirow[t]{2}{*}{ Parasitic infections } & \multicolumn{2}{|c|}{ Male } & \multicolumn{2}{|c|}{ Female } & \multicolumn{2}{|c|}{ Total } \\
\hline & No. & $\%$ & No. & $\%$ & No. & $\%$ \\
\hline Blastocystis hominis & 125 & 52.3 & 129 & 56.8 & 254 & 54.5 \\
\hline Giardia lamblia & 71 & 29.7 & 49 & 21.6 & 120 & 25.8 \\
\hline Nonpathogenic Intestinal Amebae* & 30 & 12.6 & 42 & 18.5 & 72 & 15.5 \\
\hline Entamoeba histolytica & 3 & 1.3 & 2 & 0.9 & 5 & 1.1 \\
\hline Other** & 10 & 4.2 & 5 & 2.2 & 15 & 3.2 \\
\hline Total & 239 & 100.0 & 227 & 100.0 & 466 & 100.0 \\
\hline
\end{tabular}

* includes Entamoeba coli and Endolimax nana; ** includes Hymenolepis nana, Enterobius vermicularis and Taenia infection.

Table 2

Distribution of intestinal parasites by age in a population in Shahre-Ray, Tehran, Iran

\begin{tabular}{|c|c|c|c|c|c|c|c|c|c|c|}
\hline \multirow[t]{2}{*}{ Age (year) } & \multicolumn{2}{|c|}{ Blastocystis hominis } & \multicolumn{2}{|c|}{ Nonpathogenic Amebae* } & \multicolumn{2}{|c|}{ Giardia lamblia } & \multicolumn{2}{|c|}{ Others $* *$} & \multicolumn{2}{|c|}{ Total } \\
\hline & No. $(\%)$ & $\mathrm{PP} * * *$ & No. $(\%)$ & $\mathrm{PP}$ & No. $(\%)$ & PP & No. $(\%)$ & $\mathrm{PP}$ & No. $(\%)$ & PP \\
\hline$<11$ & $35(13.8)$ & 4.6 & $12(16.7)$ & 1.6 & $31(25.8)$ & 4.1 & $6(30.0)$ & 0.8 & $84(18.0)$ & 11.1 \\
\hline $11-20$ & $50(19.7)$ & 5.7 & $11(15.3)$ & 1.3 & $25(20.8)$ & 2.9 & $1(5.0)$ & 0.1 & $87(18.7)$ & 10.0 \\
\hline $21-30$ & $74(29.1)$ & 6.2 & $16(22.2)$ & 1.3 & $26(21.7)$ & 2.2 & $8(40.0)$ & 0.7 & $124(26.6)$ & 10.4 \\
\hline $31-40$ & $44(17.3)$ & 6.6 & $12(16.7)$ & 1.8 & $17(14.2)$ & 2.6 & $0(0.0)$ & 0.0 & $73(15.7)$ & 11.0 \\
\hline $41-50$ & $28(11.0)$ & 5.2 & $9(12.5)$ & 1.7 & $12(10.0)$ & 2.2 & $4(20.0)$ & 0.7 & 53 (11.4) & 9.9 \\
\hline$>51$ & $23(9.1)$ & 6.5 & $12(16.7)$ & 3.4 & $9(7.5)$ & 2.5 & $1(5.0)$ & 0.3 & 45 (9.7) & 12.7 \\
\hline Total & $254(100.0)$ & 5.8 & $72(100.0)$ & 1.6 & $120(100.0)$ & 2.7 & $20(100.0)$ & 0.5 & $466(100.0)$ & 10.7 \\
\hline
\end{tabular}

* includes Entamoeba coli and Endolimax nana; ** includes Entamoeba histolytica, Hymenolepis nana, Enterobius vermicularis and Taenia infection; *** indicates period prevalence per 100 persons. 
In addition, prevalence of $B$. hominis infections was higher in all age groups than other parasitic infections $\left(\mathrm{P}_{(2)}>0.05\right)$. A statistically significant difference was found between age and sex among patients infected with $B$. hominis $\left(\mathrm{P}_{(2)}=0.007\right)$. In contrary, no statistically significant difference was found between age and sex among patients infected with G. lamblia $\left(\mathrm{P}_{(2)}>0.05\right)$.

The majority of the patients aged $\geq 18$ years $(54.1 \%, 170 / 331)$ showed a low level of educational attainment (e.g., illiterate, primary or junior high school) and were homemakers $(42.3 \%, 140 / 331)$ and workers $(28.1 \%, 93 / 331)$ employed in various business settings such as food, industry and construction.

\section{DISCUSSION}

The prevalence and epidemiologic features of intestinal parasites vary in different parts of the world. For instance, the prevalence of Entamoeba histolytica ranges from $5 \%$ to $81 \%$ and was suggested infecting approximately 480 million people globally ${ }^{14}$. G. lamblia was reported as the most common intestinal parasite in the United States $^{8}$. In this study, we found prevalence of intestinal parasites to be $10.7 \%$ among a population in Shahre-Ray in south of Tehran, Iran. A national epidemiologic study (1999-2000) of a random sample of the Iranian population reported a prevalence of $19.3 \%$ for intestinal parasites in Iran $^{21}$. Prevalence of intestinal parasites vary in different parts of Iran, with $66 \%$ reported from Shahr-Yar (Southeast of Tehran) ${ }^{22}, 61 \%$ in Yazd (Central of Iran) ${ }^{5}, 59 \%$ in Kermansha (West of Iran) ${ }^{26}, 56.6 \%$ in Qazvin (North of Iran) ${ }^{11}$ and $46.7 \%$ in Ilam (West of Iran $)^{2}$. Socio-economic, geographic, sanitary/hygienic, cultural, and nutritional factors may contribute to the fact that the prevalence of intestinal parasites in Iran is high and also vary across the country. Further, regional differences in the prevalence of parasites may be attributed to sample size/population and methodology used to collect the data.

Our findings showed that B. hominis and G. lamblia were the most common intestinal parasites among the study population. SAYYARI et al. ${ }^{21}$ reported that G. lamblia and Ascaris lumbricoides were the most frequent microorganisms causing intestinal parasitic infections in Iran. In a review of 300 cases of intestinal parasitic infection in Iran G. lamblia and E. histolytica were found to be the most common intestinal parasites ${ }^{12}$. In economically developing countries such as Mexico, up to $18 \%$ of cases of acute diarrhea and dysentery in children requiring hospitalization were found to be associated with $G$. lamblia as well as $10 \%$ with E. histolytica and $7 \%$ with B. hominis ${ }^{4}$.

Blastocystis hominis is a common microscopic parasitic organism found throughout the world (reported prevalence ranges between 2 to $50 \%)^{7,28}$. Although the mode of Blastocystis transmission is not fully understood, the number of people infected seems to increase in areas where sanitation and personal hygiene is inadequate ${ }^{7}$. G. lamblia is usually found in soil, food, water, or surfaces that have been contaminated with the feces from infected humans or animals and its mode of transmission is oral-fecal ${ }^{7}$. Practicing good hygiene (e.g., wash hands thoroughly with soap and water) and avoiding using contaminated water/food are the main preventive measures to prevent common intestinal parasitic infections (e.g., B. hominis and $G$. lamblia $)^{7}$. Although we did not directly investigate the aforementioned risk factors, we strongly believe that these factors are highly correlated with high prevalence of parasitic infections in the study area considering its built environment, sanitation conditions of soil, food/ water and relatively low neighborhood socioeconomic status of the area.

Studies have shown that the prevalence of intestinal parasitic infection is higher in younger people, especially children ${ }^{6}$. For instance, a large survey in Malaysia reported the overall prevalence of intestinal parasitic infections as $39.6 \%$ with as many as $89.0 \%$ in children between the ages of two and 12 years ${ }^{10}$. A large study of intestinal parasitic infections in Iran found children aged 2-14 years with a high prevalence of $25 \%{ }^{21}$. Similarly in this study, children and adolescents aged $\geq 18$ years comprised approximately one third of the patients diagnosed with intestinal parasitic infections. The prevalence of G. lamblia was found to be higher among younger children than older people. Children infected with $G$. lamblia are mostly asymptomatic and can spread the infection to other children or even within their homes and may contribute to high epidemic rates in their communities?

The prevalence of intestinal parasitic infections was slightly higher in males than females, which is comparable with previous studies in Iran including those from Tabas ${ }^{20}$, Kerman ${ }^{12}$ and Shahre-kord ${ }^{9}$. Studies from other countries reported differences in the prevalence of infections between males and females. For instance, studies among school children from Mexico ${ }^{17}$ and Palestine ${ }^{1}$ reported a higher rate of intestinal parasites among male than females, while reports from Lebanon (among adults) $)^{19}$ and Turkey (children) ${ }^{15}$ showed a higher prevalence of infections among females than males.

In this study, more than half of the patients infected with intestinal parasitic infections were with low level of education and/or were homemakers and workers. Other studies have shown an association between socioeconomic status and prevalence of parasitic infections ${ }^{15-17}$. It is necessary to further investigate this pattern possibly in a comparison study with northern districts of Tehran where the proportion of the underprivileged population is remarkably lower than the south of the city.

In summary, findings of this study emphasize that intestinal parasitic infections is a major public health challenge that needs to be addressed in order to decrease its burden on the health care system as well as the society as whole. It is noteworthy to indicate that this study along with other similar studies in Iran (i.e., SAYYARI et al. 19992000 ${ }^{21}$; MAHYAR et al. 2000 ${ }^{11}$; VOJDANI et al. 1995-199926; FIROOZABADI \& AZIZI 1999-20005; SHAHABI 199222; NIKMANESH et al. $2002^{13}$ ) suggest that Iran is still one of the endemic areas for such infections. The authors believe that public education, health promotion, improving sanitation conditions of underdeveloped areas/communities, community involvement (especially underprivileged), and supporting evidence-based practice/programs are the keys to success in preventing the spread of intestinal parasitic infections in Iran. In this regard, findings of this study can be used as a basis to develop strategies and preventive programs targeting groups at greater risk of intestinal parasitic infections. 


\section{RESUMO \\ Prevalência de parasitas intestinais em população no sul do Teerã, Irã}

O própósito deste estudo foi descrever as características epidemiológicas dos parasitas intestinais em população do sul de Teerã, Irã. Um estudo retrospectivo seccional cruzado de pacientes com suspeita de infecções parasitárias intestinais enviados ao Laboratório Zakaria Razi em Shahre-Ray, sul do Teerã, Irã foi conduzido de 21 de abril de 2004 a 20 de outubro de 2005. Todas as amostras de fezes foram examinadas e as informações sóciodemográficas recuperadas. De 4371 pacientes enviados, 466 (239 homens e 227 mulheres) foram diagnosticados laboratorialmente como portadores de parasitas intestinais com prevalência no período de $10,7 \%$. Blastocystis hominis (B. hominis) e Giardia lamblia ( $G$. lamblia) foram os parasitas intestinais mais frequentes. Mais da metade dos pacientes $\geq 18$ anos tinham baixo nível educacional (por exemplo: analfabetos, escola primária, $2^{\circ}$ grau completo) (170/331, $54,1 \%)$. Mais ainda, a maioria dos pacientes eram empregados domésticos $(42,3 \%, 140 / 331)$ ou trabalhadores $(28,1 \%, 93 / 331)$ empregados em diversos tipos de serviços, tais como a indústria de alimentos e construção. Achados deste estudo mostraram que as infecções parasitárias intestinais são ainda um desafio importante em saúde pública no Irã que necessita ser resolvido. Acreditamos que a educação pública, a melhoria das condições sanitárias em áreas pouco desenvolvidas/comunidades, envolvimento da comunidade, e programas práticos baseados nas evidências, são as principais chaves do sucesso na prevenção da disseminação das infecções parasitárias no Irã.

\section{ACKNOWLEDGMENTS}

This study was completed at Iran University of Medical Sciences in Tehran, Iran. The authors would like to thank Ms. Razavi for her assistance in data collection.

\section{REFERENCES}

1. AL-ZAIN, B. \& AL-HINDI, A. - Distribution of Strongyloides stercoralis and other intestinal parasites in household in Beit-lahia city, Gaza Strip, Palestine. Ann. Alquds Med., 1: 48-52, 2005.

2. ARBABI, M. \& TALARI, S.A. - Intestinal parasitic infections among students in Kashan Medical University. J. Ilam Univ. med. Sci., 12: 24-33, 2004.

3. CASEMORE, D.P.; ARMSTRONG, M. \& SANDS, R.L. - Laboratory diagnosis of cryptosporidiosis. J. clin Path., 12: 1337-1341, 1985.

4. DIAZ, E.; MONDRAGON, J.; RAMIREZ, E. \& BERNAL, R. - Epidemiology and control of intestinal parasites with nitazoxanide in children in Mexico. Amer. J. trop. Med. Hyg., 4: 384-385, 2003.

5. FIROOZABADI, A.A. \& AZIZI, M. - Prevalence of intestinal parasitic infections among fast-food restaurant workers in Yazd. J. Shahid Sadoghi Univ. med. Sci., 1: 29-33, 2003.

6. HELLARD, M.E.; SINCLAIR, M.I.; HOGG, G.G. \& FAIRLEY, C.K. - Prevalence of enteric pathogens among community based asymptomatic individuals. J. Gastroent. Hepat., 3: 290-293, 2000.
7. HILL, D.R. - Giardia lamblia. In: MANDELL, G.L.; BENNETT, J.E. \& DOLIN, R. Principles and practice of infectious diseases. 6. ed. New York, Churchill Livingstone, 2007. p. 2888-2893.

8. KAPPUS, K.D.; LUNDGREN Jr., R.G.; JURANEK, D.D.; ROBERTS, J.M. \& SPENCER, H.C. - Intestinal parasitism in the United States: update on a continuing problem. Amer. J. trop. Med. Hyg., 6: 705-713, 1994.

9. KOROOSH, M.N. - Prevalence of intestinal parasitic infestations in patients attending the parasitology laboratory in Shahrekord. Iranian J. Parasit., 11: 131a, 1997.

10. LEVY, J. - Epidemiological survey of intestinal parasitic infections in children of Sabah, Malaysia. Community Med., 10: 240-249, 1988.

11. MAHYAR, A.; DANESHI KOHAN, M.M.; SAGHAFI, H. \& REZAIE, M. - Intestinal parasitic infections among disabled children in Qazvin. J. Qazvin Univ. med. Sci., 2: 64-70, 2000.

12. NASER, Z.A. \& JAFAR, M. - Prevalence of intestinal parasites in the city of Kerman. Iranian J. Parasit., 11: 129a, 1997.

13. NIKMANESH, B.; OORMAZDI, H.; AKHLAGHI, L. et al. - A survey of the prevalence of some agents particularly Cryptosporidium to produce diarrhea among children referred to Tehran Children's Medical Center. J. Iran Univ. med. Sci., 14: 193-202, 2007.

14. NORHAYATI, M.; FATMAH, M.S.; YUSOF, S. \& EDARIAH, A.B. - Intestinal parasitic infections in man: a review. Med. J. Malaysia, 58: 296-305, 2003.

15. OKYAY, P.; ERTUG, S.; GULTEKIN, B.; ONEN, O. \& BESER, E. - Intestinal parasites prevalence and related factors in school children, a western city sample -Turkey. BMC publ. Hith., 4: 64, 2004.

16. PHIRI, K.; WHITTY, C.J.; GRAHAM, S.M. \& SSEMBATYA-LULE, G. - Urban/rural differences in prevalence and risk factors for intestinal helminth infection in southern Malawi. Ann. trop. Med. Parasit., 94: 381-387, 2000.

17. QUIHUI, L.; VALENCIA, M.E.; CROMPTON, D.W. et al. - Role of the employment status and education of mothers in the prevalence of intestinal parasitic infections in Mexican rural schoolchildren. BMC publ. Hlth, 6: 225, 2006.

18. RIDLEY, D.S. \& HAWGOOD, B.C. - The value of formol-ether concentration of faecal cysts and ova. J. clin. Path., 9: 74-76, 1956.

19. SAAB, B.R.; MUSHARRAFIEH, U.; NASSAR, N.T.; KHOGALI, M. \& ARAJ, G.F. Intestinal parasites among presumably healthy individuals in Lebanon. Saudi med. J., 25: 34-37, 2004.

20. SAIED, H.M. - Prevalence of intestinal parasites in Tabas city. Tehran, Tehran University School of Health Sciences and Research Institute, 1999.

21. SAYYARI, A.A.; IMANZADEH, F.; BAGHERI YAZDI, S.A.; KARAMI, H. \& YAGHOOBI, M. - Prevalence of intestinal parasitic infections in the Islamic Republic of Iran. East Mediterr. HIth J., 11: 377-383, 2005.

22. SHAHABI, S. - Epidemiologic study of intestinal parasites among elementary school children in Shahr-Yar. Research Med., 24: 133-139, 2001.

23. SOHEILI AZAD, A.A.; NOURJAH, D. \& SHAHBAZI, F. - Relationship between parasite infection and malnutrition in Robat Karim elementary school students. J. Iran Univ. med. Sci., 45(12): 87-96, 2006.

24. STATISTICAL CENTER OF IRAN - Publications Information Base. http:// amar.sci.org.ir/ (Accessed on Jan. 20, 2008).

25. STATISTICAL PROGRAM FOR SOCIAL SCIENCES (SPSS) - $\mathbf{1 1 . 0}$ for Windows. Chicago, SPSS, 2001.

26. VOJDANI, M.; BARZEGHAR, A. \& SHAMSIAN, A. - A study of intestinal parasites among patients treated at the Kermansha Medical University clinic. J. Kermansha Univ. med. Sci., 81(2): 31-38, 2002. 


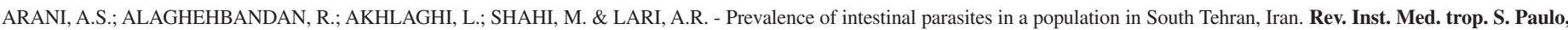
50(3): 145-149, 2008.

27. WHO - Medios auxiliaries para el diagnostico de las parasitosis intestinales. Geneva, World Health Organization, 1994.

28. WHO - Water, sanitation and hygiene, Blastocystis. Geneva, World Health Organization, 2003. http://www.who.int/water_sanitation_health/gdwqrevision/ phe_wsh_blasty_fact\%20_sheet.pdf (Accessed on April 5, 2008).
29. XU, L.Q.; YU, S.H.; JIANG, Z.X. et al. - Soil-transmitted helminthiases: nationwide survey in China. Bull. Wld Hlth Org., 73: 507-513, 1995.

Received: 31 July 2007

Accepted: 7 April 2008 